\title{
Boston cardiologist faces charges of embezzlement
}

Boston. A leading heart researcher at the Harvard Medical School and former chief of cardiology at the Boston Children's Hospital, who had surprised his colleagues with a lifestyle that included the purchase of an impressive collection of modern art, was last week indicted by a grand jury on six counts of embezzlement.

The indictments, which were announced by Scott Harshbarger, the attorney-general of Massachusetts, accuse Bernardo NadalGinard of misappropriating $\$ 130,000$ from the Boston Children's Heart Foundation, a non-profit cardiology group practice affiliated with the Children's Hospital.

Nadal-Ginard has been charged with diverting money from the foundation - for whom he had previously served as both president and treasurer - into his personal bank accounts on six separate occasions during 1992.

"The criminal laws must be used to root out white collar fraud at all levels, regardless of one's position or socio-economic status" said Harshbarger in a press statement. "This defendant allegedly violated his position of trust and authority to steal from charitable institutions dedicated to providing important medical care."

The investigation leading to the indictments began last October after both the hospital and the foundation had notified Harshbarger's office of "financial irregularities". In November, Nadal-Ginard was placed on unpaid leave by both the medical school and the hospital, which is a Harvard teaching hospital.

$\mathrm{He}$ was dismissed from the hospital, where he directed a laboratory with a staff of 60 scientists and technicians, on 31 December. Carol Weinrib, the vice-president of the hospital, says that the future of those employed in the laboratory is uncertain, but that an "orderly transition" is being planned.

If convicted, the cardiologist faces a maximum sentence of five years in a state prison and a fine of $\$ 25,000$ on each embezzlement charge. The spokesperson refused to comment on what Nadal-Ginard may have done with the money he is accused of stealing, although sources close to the case claim that much of it was used to enlarge his art collection.

Nadal-Ginard is already the subject of a separate suit which was filed last November, by his former colleagues at the Childrens Heart Foundation. These claim that he received "unreasonable and excessive compensation" by withdrawing more than $\$ 4$ million from a pension fund and drawing a salary of more than $\$ 500,000$, considerably in excess of the limit allowed under the rules of Harvard Medical School. Steve Nadis

\section{Conflict-of-interest debate stirs mixed reaction at NIH}

Washington. The proposed sponsored research agreement between Scripps Research Institute and the Sandoz drugs company, which provoked widespread controversy when it was announced last year, was anomalous and is unlikely to be replicated elsewhere, according to Sandy Chamblee, acting deputy director of the US National Institutes of Health (NIH).

But whether the problems caused by such sponsorship agreements are real (as the media tend to suggest) or not (as many scientists would claim), Congress told NIH to fix them after hearings last June before a subcommittee chaired by Ron Wyden

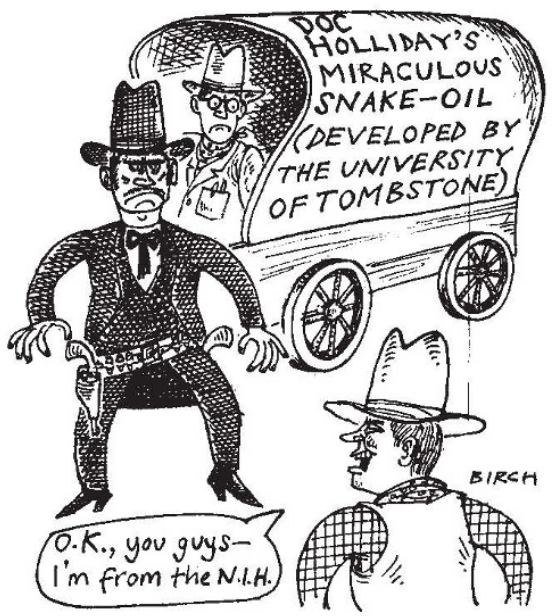

(Democrat, Oregon). And the NIH is now taking steps to do so.

The \$300-million agreement between Scripps and Sandoz was effectively blocked by NIH as a result of public concern that it would have given the company excessive control over the results of federally funded research.

But Chamblee told a meeting in Bethesda, Maryland last week of a panel convened to advise NIH on the future regulation of such agreements that a survey of 375 sponsored research deals across a hundred leading US research institutions found none of the others remotely close in either scale or scope to that proposed between Scripps and Sandoz.

Many scientists and industrialists involved in sponsored research agreements believe that most of them work to the public good. Universities have been actively encouraged to transfer technology to the private sector since the passage of the BayhDole act of 1980 , which set the current framework for such agreements.

But, as the main source of public funds for biomedical research in the United States, the NIH pays for most work done at Scripps (and elsewhere). Congress - not unreasonably - wants NIH to ensure that the tax- payer is not being fleeced by agreements that give too much away to the industrial sponsors of other research projects carried out at these institutions.

Items that have generated concern include excessively broad agreements that encompass all areas of research, deals that exclude rival companies from access to unused ideas and provisions that restrict the freedom of researchers to publish and discuss their work.

The problem, as panel member Robert Merges, professor of law at Boston University, points out, is that NIH was not set up as a regulatory body, but is having to devise a policy that is both effective and simple to administer. "It's a tough goal," says Merges.

There is a range of views on how tight the guidelines need to be. Some advocate minimal interference. "We are doing this because someone asked us to, not because there's really an issue out there," says Donald Drakeman, chief executive of Medarex and an industrialist advising the panel.

But Paul Berg, professor of biochemistry at Stanford Medical Center, claimed that the current system is destroying pure, discovery-based science in US universities. "We sit here and talk about feeding ideas into American industry, but we ignore the price we will pay," he said.

Despite Berg's complaints, the predominant view on the NIH panel was that technology transfer under Bayh-Dole has been a big success, only temporarily blemished by the Scripps-Sandoz episode. But Congressman Wyden's subcommittee still expects NIH to provide some firm conflictof-interest rules for universities.

Last week's panel discussion will lead to a report for an NIH internal task force led by Chamblee, which will in turn prepare draft guidelines for Harold Varmus, the director of NIH, to take to his own advisory committee's next meeting in June.

The guidelines are expected to include a set of thresholds above which the university must obtain the approval of the NIH. Typical suggestions are that such approval should be sought for agreements worth more than $\$ 5$ million, or involving more than one fifth of the work funded by NIH at a given institution.

Universities would retain responsibility for the details of smaller deals. But they would be reminded of their obligation to protect the academic freedom of their staff.

NIH hopes that by addressing the issue publicly, it can help to dispel uncomfortable memories of the Scripps-Sandoz affair, and show that most sponsored research agreements are working in the public interest.

Colin Macilwain 